\title{
Plasmodium knowlesi and HIV co-infection in a German traveller to Thailand
}

\author{
Jonas Ehrhardt ${ }^{1}$, Andreas Trein ${ }^{2}$, Peter Gottfried Kremsner ${ }^{1}$ and Matthias Frank ${ }^{1 *}$
}

\begin{abstract}
A case of Plasmodium knowlesi and HIV co-infection is reported in a German traveller returning from Thailand. The 54 year-old patient presented to the Institute of Tropical Medicine in Tübingen with a 11-day history of daily fever and chills. Initial microscopic evaluation of Giemsa-stained thin blood smears was suggestive of a mixed infection with Plasmodium falciparum and Plasmodium malariae. However, PCR amplification of small subunit ribosomal RNA gene revealed a $P$. knowlesi infection. Parasitaemia was 473 parasites/ $\mu$ and the platelet count was within the normal range. Oral treatment with Malarone ${ }^{\varpi}$ was initiated and resulted in a fast recovery without any complications.

As part of routine screening the patient also underwent HIV testing and was found to be HIV positive with a CD4 cell count of 115/ $\mathrm{\mu l}$ and a viral load of 34,799 copies $/ \mathrm{ml}$. A follow-up measurement of the viral load seven days after the first quantification revealed an increase to 102,000 copies/ml. Three months after the first quantification the viral load had dropped to 10,000 copies/ml without the initiation of antiretroviral treatment. This suggests the possibility of a P. knowlesi malaria-induced temporary elevation of viral load similar to that reported for P. falciparum and HIV co-infection.
\end{abstract}

Keywords: Plasmodium knowlesi, Traveller, Thailand, Plasmodium knowlesi HIV co-infection, Viral load, Malaria, Malarone ${ }^{\oplus}$, Severity

\section{Background}

In the last eight years a growing body of literature confirmed the existence of a fifth species of Plasmodium capable of causing human malaria. The fifth species is Plasmodium knowlesi, a malaria parasite naturally circulating in long-tailed (Macaca fascicularis) and pig-tailed (Macaca nemestrina) macaques in Southeast Asia. In 2004, Singh and colleagues described the first large focus of naturally acquired P. knowlesi infections in humans in the Kapit division of Sarawak (Malaysian Borneo) [1]. Thereafter, numerous reports followed and confirmed the existence of human $P$. knowlesi infections throughout Malaysian Borneo [2-5] and Peninsular Malaysia [2,6], as well as nearly every country in Southeast Asia (Myanmar [7], Vietnam [8], Philippines [9], Thailand [10], Cambodia [11], Singapore [12]). The frequency of P. knowlesi in patients with microscopically diagnosed malaria ranges from less than $1 \%$ (e g, in Thailand) [10] to up to $60 \%$ (Malaysian Borneo) [5]. Since 2004, twelve cases of

\footnotetext{
*Correspondence: matthias.frank@uni-tuebingen.de

1 Institute of Tropical Medicine, University of Tübingen, Wilhelmstr. 27.

Tübingen 72074, Germany

Full list of author information is available at the end of the article
}

imported $P$. knowlesi malaria to non-endemic countries have been published [13-24]. Eleven cases developed uncomplicated malaria and were successfully treated with common anti-malarial drugs, one patient improved spontaneously (without receiving treatment) [22]. However, lethal outcomes due to $P$. knowlesi malaria have been described in Southeast Asia. Case-fatality rates of 2\% (district hospital) [25] and 11\% (referral hospital) [26] have been reported. No deaths occured in a recent prospective study in a referral hospital in Malaysian Borneo, where severe $P$. knowlesi cases were treated with oral artesunate combination therapy or intravenous artesunate [27].

It has been reported that HIV infection increases the susceptibility to malaria $[28,29]$ and the risk of developing severe Plasmodium falciparum malaria [30-33]. At the same time $P$. falciparum malaria causes a transient elevation of viral load in HIV-positive individuals [34-36]. The interactions between malaria and HIV have been studied mainly in African countries with P. falciparum-infected patients. There is currently no published information about $P$. knowlesi malaria and HIV co-infection available. This is the first description of $P$. knowlesi malaria in an HIV-positive adult with advanced immunosuppression. 


\section{Case presentation}

A 54 year-old German traveller presented to the Institute of Tropical Medicine in Tübingen with fever, chills and severe headaches. Twenty days prior to presentation the patient had returned from a four-week trip to southern Thailand where he visited with his Thai wife. He stayed nearly all the time in Phuket and never took malaria chemoprophylaxis (please see below for a more detailed description of the trip). Eleven days prior to presentation the symptoms started with a sudden onset of fever (initially up to $40^{\circ} \mathrm{C}$ ) and chills. Thereafter fever decreased gradually, but the patient continued to experience low grade fevers around $38.5^{\circ} \mathrm{C}$ until the day of presentation. Eight days prior to presentation the patient noticed a temporary rash on the lower limbs that he related to the intermittent use of Paracetamol. On examination, the patient was in no acute distress but appeared fatigued. The temperature was $37.4^{\circ} \mathrm{C}$ and vital signs were stable (blood pressure 120/ $75 \mathrm{mmHg}$, heart rate of 86 beats per minute). With the exception of tenderness in the left upper abdominal quadrant the physical examination was unremarkable. Abdominal ultrasound revealed mild splenomegaly $(14.1 \times 6.2 \mathrm{~cm})$. Laboratory tests showed mild anaemia (haemoglobin $12.5 \mathrm{~g} / \mathrm{dl}$, normal $14-18 \mathrm{~g} / \mathrm{dl}$ ), elevation of lactate dehydrogenase (351 U/l, normal <251 U/l) and C-reactive protein $(2.39 \mathrm{mg} / \mathrm{dl}$, normal $<0.51 \mathrm{mg} / \mathrm{dl})$. Values were normal for platelet count $(197,000 / \mu \mathrm{l}$, normal $150,000-400,000 / \mu \mathrm{l})$, white cell count $(4.100 / \mu \mathrm{l}$, normal $4,000-9,500 / \mu \mathrm{l})$, total bilirubin $(0.8 \mathrm{mg} / \mathrm{dl}$, normal $<1,2 \mathrm{mg} / \mathrm{dl})$ and plasma creatinine $(0.9 \mathrm{mg} / \mathrm{dl}$, normal $0.6-1.1 \mathrm{mg} / \mathrm{dl})$. Rapid diagnostic tests for dengue were negative (Dengue Dx IgG/IgM and NS1 Antigen Rapid Test, Focus Diagnostics, USA). Giemsa-stained thick and thin blood smears showed the presence of malaria parasites (Figure 1). Using the Lambaréné method parasitaemia was estimated to be about $0.01 \%$ ( 473 parasites $/ \mu \mathrm{l})$. Microscopic evaluation of thin blood smears revealed several ring stage parasites with a morphology reminiscent of $P$. falciparum ring stage parasites. However, several late trophozoite stage parasites with haemozoin pigment as well as gametocytes with a size of an uninfected red blood cell were identified. Based on these morphologic features the presumptive diagnosis of a co-infection with $P$. falciparum and Plasmodium malariae was made. Treatment with atovaquone/proguanil $250 \mathrm{mg} /$ $100 \mathrm{mg}$ (four tablets/day for three days) was initiated and the patient was admitted to the hospital. During antimalarial therapy the parasitaemia cleared rapidly. Serial blood smears revealed a parasitaemia of $70 / \mu \mathrm{l}$ after 24 hours and $11 / \mu \mathrm{l}$ after 48 hours of therapy. The platelet count after 24 hours and 48 hours of therapy was $249.000 / \mu$ l and $257.000 \mu \mathrm{l}$ respectively.

Due to the uncertain blood smear identification of Plasmodium species, small subunit ribosomal RNA gene PCR amplification was performed. The PCR fragment was sequenced and a BLAST search in the GenBank database (basic local alignment search tool) showed a 96\%-match with $P$. knowlesi sequences. No other human plasmodial species were identified by the BLAST search. The patient was discharged after three days in improved conditions.

In addition, at day of presentation HIV testing was performed as part of routine screening. The patient's last testing dated four years back and had been negative.
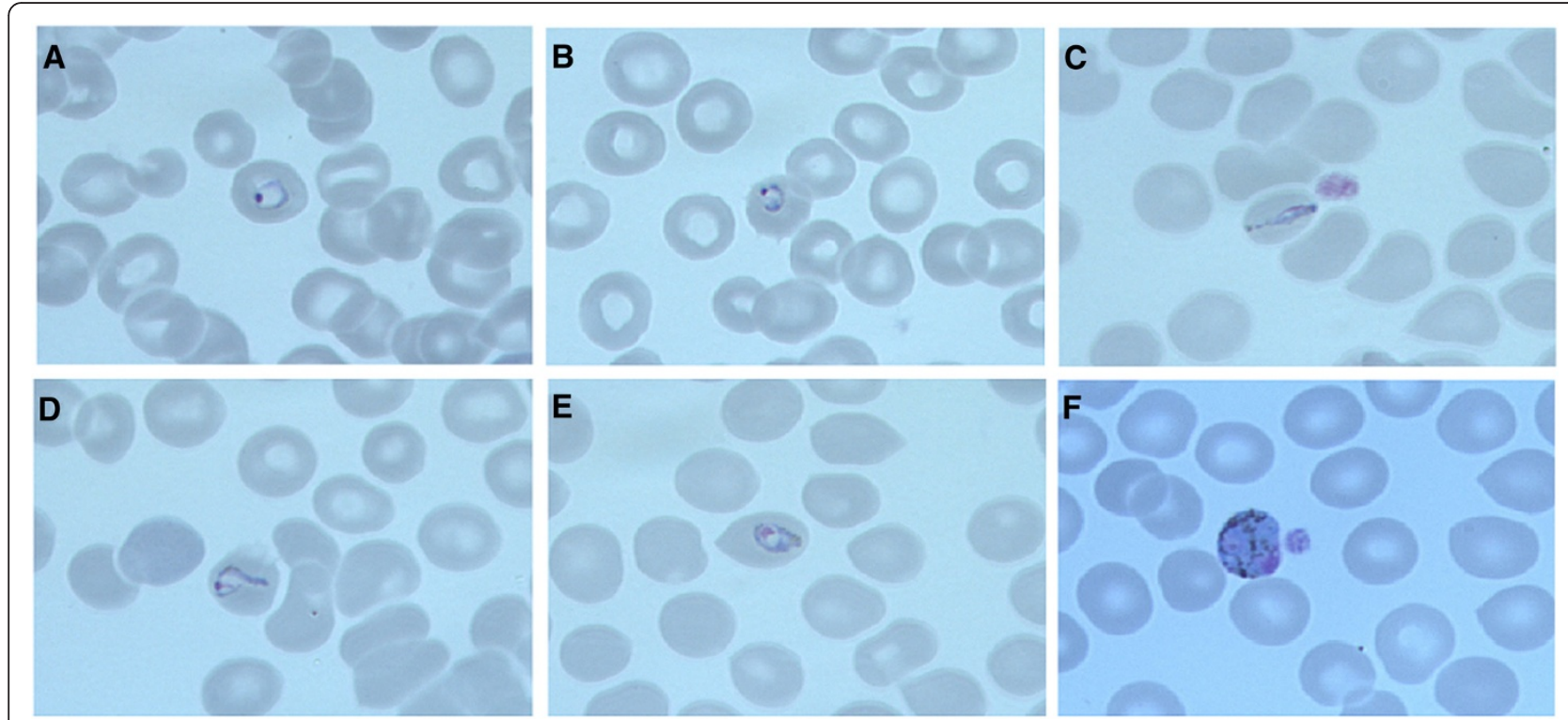

Figure 1 Giemsa-stained thin blood smears with Plasmodium knowlesi parasites (magnification: 100x, oil immersion). Panels A and B display ring stage parasites. Panel $\mathbf{C}$ shows a band-form. Panels $\mathbf{D}$ and $\mathbf{E}$ show late trophozoite parasites. Panel $\mathbf{F}$ displays a gametocyte. 
Now HIV-1-antibodies were detected by ELISA and confirmed by Western blot. The CD4 cell count was $115 / \mu \mathrm{l}$ and viral load was 34,799 copies/ml. On repeated questioning the patient reported that the relationship with his Thai wife started four years ago. At that point both partners underwent HIV testing and were found to be HIV negative. During the patient's yearly visits to Thailand the couple had unprotected intercourse. The patient stated that except for his wife he had not had any other sexual partners for the last four years. An illness suggestive of acute HIV could not be recalled.

Seven days after the day of presentation the viral load measurement was repeated at an outside physician's office and showed an increase to 102,000 copies $/ \mathrm{ml}$. Eleven days after the day of presentation the patient presented for a follow-up examination. The physical examination was without pertinent positive findings. However, the patient continued to complain about fatigue and night sweats. A repeat blood smear was negative for malarial parasites. The complete blood count revealed a white blood cell count of 3,200 cells/ $\mu \mathrm{l}$ and unchanged haemoglobin of $12.2 \mathrm{~g} / \mathrm{dl}$. The values for lactate dehydrogenase and C-reactive protein were within normal limits. More detailed questioning of the travel history revealed that the patient had stayed three weeks at his house in Phuket where he lived with his wife. From the last week of the four-week trip he had spend three days in Ranong Province (southern part of the border to Myanmar). He noted that while walking in the local forests and fishing in the Andaman Sea he suffered a lot of mosquito bites. There was no contact with monkeys reported. For long-term HIV care the patient was referred to a specialized HIV centre. Five weeks after the $P$. knowlesi infection the viral load follow-up revealed a drop to $17,000 \mathrm{copies} / \mathrm{ml}$ without antiretroviral therapy. Three months after the $P$. knowlesi infection, viral load was 10,000 copies/ml still without antiretroviral therapy. The CD4 cell count was $204 / \mu \mathrm{l}$ and $264 / \mu \mathrm{l}$ respectively (Table 1 ).

According to official guidelines [37], the patient met criteria for the initiation of antiretroviral therapy. The necessity of starting antiretroviral therapy was repeatedly discussed with the patient. However, he repeatedly rejected this due to his personal attitude towards conventional medicine and instead expressed hope of spontaneous improvement.

Table 1 Development of the viral load and CD4 count

\begin{tabular}{|c|c|c|c|c|}
\hline & Day $1^{*}$ & Day 7 & $\begin{array}{c}\text { Day } 37 \\
\text { (week 5) }\end{array}$ & $\begin{array}{c}\text { Day } 87 \\
\text { (week 12) }\end{array}$ \\
\hline Viral load (copies/ $\mu$ l) & 34799 & 102000 & 17000 & 10000 \\
\hline 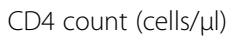 & 115 & 223 & 204 & 264 \\
\hline
\end{tabular}

*Day of presentation of the patient with acute P. knowlesi malaria.

\section{Conclusions}

Plasmodium knowlesi cases have been detected in several regions of Thailand mainly in forestal areas bordering Cambodia in the east, Malaysia in the south and Myanmar in the north-west [10]. A recent study confirmed the transmission of P. knowlesi in Ranong Province (southern part of the border to Myanmar) [38], where the here presented patient stayed for three days and where he most likely acquired the infection. The overall incidence of P. knowlesi malaria in Thailand is low. Among 1874 febrile patients attending malaria clinics in different areas of Thailand the overall prevalence of P. knowlesi was $0.57 \%$ [10]. Nevertheless, this is already the second imported case of a travel-related $P$. knowlesi infection acquired in Thailand [21]. This indicates that even short-term travellers are at risk of $P$. knowlesi infections and that due to increasing travel activities to Southeast Asia, imported P. knowlesi malaria might become more important in non-endemic countries.

During the initial questioning the patient stated that he had stayed all the time of the voyage in Phuket where Plasmodium species transmission is minimal [39] and no cases of $P$. knowlesi infections have been reported. Only on repeat questioning during the follow-up visit did the patient recall a short visit to Ranong Province. This serves as a reminder that malaria has to be excluded in returning travellers from Thailand, even if they report primarily visiting areas with very low incidence of malaria.

It has been shown for P. falciparum malaria that HIVpositive individuals have a temporarily increased viral load during acute malaria [34-36]. Kublin and colleagues described an increase of viral load during symptomatic malaria (median log increase of $0.42, \mathrm{p}<0.0001$ ) and a subsequent decrease of viral load back to baseline eight weeks after anti-malarial treatment [34]. A similar observation could be made in the here presented HIV-positive adult with acute $P$. knowlesi malaria. A baseline measurement before the acute malaria infection was not available as the HIV infection was diagnosed for the first time. Nevertheless, an increase in viral load was observed shortly after the $P$. knowlesi infection with a subsequent drop at follow-up examinations five and 12 weeks later without the initiation of antiretroviral therapy. These findings suggest a possible influence of acute $P$. knowlesi malaria on pre-existing HIV infection, resulting in a temporary increase in viral load as it has been described for acute $P$. falciparum malaria. However, as this is an observation in one patient it is necessary to assess more cases in order to confirm this finding.

The described finding raises the question as to whether there are other similarities between clinical characteristics of HIV-P. falciparum co-infection and those of HIV-P. knowlesi co-infection. Most P. knowlesi-infected individuals develop clinically uncomplicated malaria, but severe 
cases with lethal outcomes have been described recently [2]. It has been shown for P. falciparum malaria that HIVpositivity is a risk factor for the development of severe malaria and death [30-33]. In a prospective cohort study in South Africa, HIV-infected individuals with a CD4 cell count $<200 / \mu \mathrm{l}$ had an increased risk of severe malaria (odds ratio 4.8) [30]. Two studies investigating imported $P$. falciparum malaria to non-endemic countries showed that severe malaria was more frequent in patients with a CD4 cell count $<350 / \mu l$, (odds ratio 2.5 and 3.2) [32,33].

The clinical course of the $P$. knowlesi malaria case described here was uncomplicated despite marked immunosuppression of the patient (115 CD4 positive cells/ $\mu \mathrm{l}$ ). Two research groups recently established the hight of parasitaemia as a good predictor for the risk of severe disease $(\geq 35,000$ parasites $/ \mu \mathrm{l}[40]$ and $>20,000$ parasites $/ \mu \mathrm{l}$ [27]). The parasitaemia observed in the here presented patient was relatively low (473 parasites/ $\mu \mathrm{l})$. Therefore the uncomplicated course of the patients' disease supports the apparent correlation of height of parasitaemia and severity of disease in P. knowlesi malaria. Anaemia was mild and there was neither acidosis nor renal failure, which are frequently associated with severe $P$. knowlesi infections $[26,40]$.

Interestingly, thrombocytopaenia, which is nearly universal in patients with $P$. knowlesi infection [25-27], was not present. However, it is important to note that the platelet count was at the lower limit of the normal range on presentation and increased after the beginning of antimalarial therapy. It has recently been published that thrombocytopaenia in P. knowlesi malaria improves on average 24 hours after successful parasite clearance, suggesting a possible relation between $P$. knowlesi parasitaemia and a decreased platelet count [27]. It is therefore possible that the low parasitaemia of the described patient resulted in a relative small decrease of the platelet count. In addition the nadir of the platelet count may have occurred prior to presentation since the patient only presented eleven days after the onset of symptoms. Previous $P$. knowlesi cases that are published without the development of thrombocytopaenia include a 11-year old boy with chronic myeloid leukaemia taking imatinib [5] and two asplenic patients [27]. Taken together those cases suggest a possible immune-related component in the development of thrombocytopaenia during acute $P$. knowlesi malaria. It is tempting to speculate that the HIV co-infection contributed to the absence of thrombocytopaenia in the presented case, however it is not possible to address this question on the basis of a single case report.

The current case is the first description of $P$. knowlesi malaria in an HIV-positive adult with advanced immunosuppression. The patient experienced a temporary elevation of the viral load that might have been due to the acute P. knowlesi malaria. Despite advanced immunosuppression the patient's laboratory parameters were not suggestive of a severe $P$. knowlesi infection and he had an uncomplicated clinical course.

\section{Consent}

Written informed consent was obtained from the patient for publication of this case report and any accompanying images. A copy of the written consent is available for review by the Editor-in-Chief of this journal.

\section{Abbreviations \\ BLAST: Basic local alignment search tool; CD: Cluster of differentiation; HIV: Human immunodeficiency virus; PCR: Polymerase chain reaction.}

\section{Competing interests}

The authors declare that they have no competing interests.

\section{Authors' contributions}

JE reviewed the literature, conducted the collection and interpretation of data and drafted the manuscript. AT helped with the data collection and data interpretation and revised the manuscript. PK provided conceptual advice. MF revised the manuscript, helped to interpret data, helped to draft the manuscript and has given final approval of the version to be published. All authors read and approved the final manuscript.

\section{Acknowledgements}

We would like to thank the patient for his contribution to the study of $P$. knowlesi and HIV co-infection through the publication of this case report. We would like to thank Mrs Beate Salten, Mrs Judith Kammer and Mrs Helena Müller for performing the laboratory procedures.

We acknowledge support by Deutsche Forschungsgemeinschft and Open Access Publishing fund of University Tuebingen.

\section{Author details}

${ }^{1}$ Institute of Tropical Medicine, University of Tübingen, Wilhelmstr. 27, Tübingen 72074, Germany. ${ }^{2}$ Group practice Schwabstraße 59, Schwabstraße 59, Stuttgart 70197, Germany.

Received: 8 March 2013 Accepted: 29 July 2013

Published: 13 August 2013

\section{References}

1. Singh B, Kim Sung L, Matusop A, Radhakrishnan A, Shamsul SS, Cox-Singh J, Thomas A, Conway DJ, Singh B, Kim Sung L, Matusop A, Radhakrishnan A, Shamsul SS, Cox-Singh J, Thomas A, Conway DJ: A large focus of naturally acquired Plasmodium knowlesi infections in human beings. Lancet 2004, 363:1017-1024.

2. Cox-Singh J, Davis TM, Lee KS, Shamsul SS, Matusop A, Ratnam S, Rahman HA, Conway DJ, Singh B: Plasmodium knowlesi malaria in humans is widely distributed and potentially life threatening. Clin Infect Dis 2008, 46:165-171.

3. Joveen-Neoh WF, Chong KL, Wong CM, Lau TY: Incidence of malaria in the interior division of sabah, malaysian borneo, based on nested PCR. J Parasitol Res 2011, 2011:104284.

4. Naing DKS, Anderios F, Lin Z: Geographic and ethnic distribution of $P$. Knowlesi infection in Sabah, Malaysia. Int J Collab Res Intern Med Public 2011, 3:391-400.

5. Barber BE, William T, Dhararaj P, Anderios F, Grigg MJ, Yeo TW, Anstey NM: Epidemiology of Plasmodium knowlesi malaria in north-east Sabah, Malaysia: family clusters and wide age distribution. Malar J 2012, 11:401.

6. Vythilingam I, Noorazian YM, Huat TC, Jiram Al, Yusri YM, Azahari AH, Norparina I, Noorrain A, Lokmanhakim S: Plasmodium knowlesi in humans, macaques and mosquitoes in peninsular Malaysia. Parasit Vectors 2008, 1:26.

7. Jiang N, Chang Q, Sun X, Lu H, Yin J, Zhang Z, Wahlgren M, Chen Q: Co-infections with Plasmodium knowlesi and other malaria parasites, Myanmar. Emerg Infect Dis 2010, 16:1476-1478. 
8. Van den Eede P, Van HN, Van Overmeir C, Vythilingam I, Duc TN, Hung le X, Manh HN, Anné J, D'Alessandro U, Erhart A: Human Plasmodium knowlesi infections in young children in central Vietnam. Malar J 2009, 8:249.

9. Luchavez J, Espino F, Curameng P, Espina R, Bell D, Chiodini P, Nolder D, Sutherland C, Lee KS, Singh B: Human Infections with Plasmodium knowlesi, the Philippines. Emerg Infect Dis 2008, 14:811-813.

10. Putaporntip C, Hongsrimuang T, Seethamchai S, Kobasa T, Limkittikul K, Cui $L$, Jongwutiwes S: Differential prevalence of Plasmodium infections and cryptic Plasmodium knowlesi malaria in humans in Thailand. J Infect Dis 2009, 199:1143-1150.

11. Khim N, Siv S, Kim S, Mueller T, Fleischmann E, Singh B, Divis PC, Steenkeste N, Duval L, Bouchier C, Duong S, Ariey F, Menard D: Plasmodium knowlesi infection in humans, Cambodia, 2007-2010. Emerg Infect Dis 2011, 17:1900-1902

12. Ng OT, Ooi EE, Lee CC, Lee PJ, Ng LC, Pei SW, Tu TM, Loh JP, Leo YS: Naturally acquired human Plasmodium knowlesi infection, Singapore. Emerg Infect Dis 2008, 14:814-816.

13. Tanizaki R, Ujiie M, Kato Y, Iwagami M, Hashimoto A, Kutsuna S, Takeshita N, Hayakawa K, Kanagawa S, Kano S, Ohmagari N: First case of Plasmodium knowlesi infection in a Japanese traveller returning from Malaysia. Malar J 2013, 12:128.

14. Bronner U, Divis PC, Färnert A, Singh B: Swedish traveller with Plasmodium knowlesi malaria after visiting Malaysian Borneo. Malar J 2009, 8:15.

15. Van Hellemond JJ, Rutten M, Koelewijn R, Zeeman AM, Verweij JJ, Wismans PJ, Kocken CH, Van Genderen PJ: Human Plasmodium knowlesi infection detected by rapid diagnostic tests for malaria. Emerg Infect Dis 2009, 15:1478-1480.

16. Van Hellemond JJ, Van Genderen PJ: Monkey malaria in a traveller from Malaysia. Ned Tijdschr Geneeskd 2010, 154:A1353.

17. Hoosen A, Shaw MT: Plasmodium knowlesi in a traveller returning to New Zealand. Travel Med Infect Dis 2011, 9:144-148.

18. Figtree M, Lee R, Bain L, Kennedy T, Mackertich S, Urban M, Cheng Q, Hudson BJ: Plasmodium knowlesi in human, Indonesian Borneo. Emerg Infect Dis 2010, 16:672-674.

19. Kantele A, Marti H, Felger I, Müller D, Jokiranta TS: Monkey malaria in a European traveler returning from Malaysia. Emerg Infect Dis 2008, 14:1434-1436

20. Centers for Disease Control and Prevention (CDC): Simian malaria in a U.S. traveler--New York, 2008. MMWR Morb Mortal Wkly Rep 2009, 58:229-232.

21. Berry A, Iriart X, Wilhelm N, Valentin A, Cassaing S, Witkowski B, Benoit-Vical F, Menard S, Olagnier D, Fillaux J, Sire S, Le Coustumier A, Magnaval JF: Imported Plasmodium knowlesi malaria in a French tourist returning from Thailand. Am J Trop Med Hyg 2011, 84:535-538.

22. Tang TT, Salas A, Ali-Tammam M, Martínez Mdel C, Lanza M, Arroyo E, Rubio JM: First case of detection of Plasmodium knowlesi in Spain by Real Time PCR in a traveller from Southeast Asia. Malar J 2010, 9:219.

23. Kuo M-C, Chiang T-Y, Chan C-W, Tsai W-S, Ji D-D: A case report of simian malaria, Plasmodium knowlesi, in a Taiwanese traveller from Plawan island, the Philippines. Taiwan Epidemiol Bull 2009, 25:178-191.

24. Link L, Bart A, Verhaar N, Van Gool T, Pronk M, Scharnhost V: Molecular detection of Plasmodium knowlesi in a Dutch traveller by real-time PCR J Clin Microbiol 2012, 50:2523-2524.

25. Daneshvar C, Davis TM, Cox-Singh J, Rafa'ee MZ, Zakaria SK, Divis PC, Singh B: Clinical and laboratory features of human Plasmodium knowlesi infection. Clin Infect Dis 2009, 49:852-860.

26. William T, Menon J, Rajahram G, Chan L, Ma G, Donaldson S, Khoo S, Frederick C, Jelip J, Anstey NM, Yeo TW: Severe Plasmodium knowlesi malaria in a tertiary care hospital, Sabah, Malaysia. Emerg Infect Dis 2011, 17:1248-1255.

27. Barber BE, William T, Grigg MJ, Menon J, Auburn S, Marfurt J, Anstey NM, Yeo TW: A prospective comparative study of knowlesi, falciparum, and vivax malaria in Sabah, Malaysia: high proportion with severe disease from Plasmodium knowlesi and Plasmodium vivax but no mortality with early referral and artesunate therapy. Clin Infect Dis 2013, 56:383-97.

28. Patnaik P, Jere CS, Miller WC, Hoffman IF, Wirima J, Pendame R, Meshnick SR, Taylor TE, Molyneux ME, Kublin JG: Effects of HIV-1 serostatus, HIV-1 RNA concentration, and CD4 cell count on the incidence of malaria infection in a cohort of adults in rural Malawi. J Infect Dis 2005, 192:984-991.

29. Uneke CJ, Ogbu O, Inyama PU, Anyanwu Gl: Malaria infection in HIV-seropositive and HIV-seronegative individuals in Jos-Nigeria. J Vector Borne Dis 2005, 42:151-154.
30. Cohen C, Karstaedt A, Frean J, Thomas J, Govender N, Prentice E, Dini L, Galpin J, Crewe-Brown H: Increased prevalence of severe malaria in HIV-infected adults in South Africa. Clin Infect Dis 2005, 41:1631-1637.

31. Grimwade K, French N, Mbatha DD, Zungu DD, Dedicoat M, Gilks CF: HIV infection as a cofactor for severe falciparum malaria in adults living in a region of unstable malaria transmission in South Africa. AIDS 2004, 18:547-554

32. Mouala C, Houzé S, Guiguet M, Abboud P, Pialoux G, Viget N, Costagliola D, Matheron S: Imported malaria in HIV-infected patients enrolled in the ANRS CO4 FHDH study. J Acquir Immune Defic Syndr 2008, 49:55-60.

33. Mouala C, Guiguet M, Houzé S, Damond F, Pialoux G, Viget N, Costagliola D, Le Bras J, Matheron S, FHDH-ANRS CO4 Clinical Epidemiology Group: Impact of HIV infection on severity of imported malaria is restricted to patients with CD4 cell counts $<350$ cells/microl. AIDS 2009, 23:1997-2004.

34. Kublin JG, Patnaik P, Jere CS, Miller WC, Hoffman IF, Chimbiya N, Pendame R, Taylor TE, Molyneux ME: Effect of Plasmodium falciparum malaria on concentration of HIV-1-RNA in the blood of adults in rural Malawi: a prospective cohort study. Lancet 2005, 365:233-240.

35. Hoffman IF, Jere CS, Taylor TE, Munthali P, Dyer JR, Wirima JJ, Rogerson SJ, Kumwenda N, Eron JJ, Fiscus SA, Chakraborty H, Taha TE, Cohen MS, Molyneux ME: The effect of Plasmodium falciparum malaria on HIV-1 RNA blood plasma concentration. AIDS 1999, 13:487-494.

36. Watt G, Kantipong P, De Souza M, Chanbancherd P, Jongsakul K, Ruangweerayud R, Loomis-Price LD, Polonis V, Myint KS, Birx DL, Brown AE, Krishna S: HIV-1 suppression during acute scrub-typhus infection. Lancet 2000, 356:475-479.

37. EACS: European Treatment Guidelines. Version 6.1. European AIDS Clinical Society: Paris; 2012. http://www.europeanaidsclinicalsociety.org/images/ stories/EACS-Pdf/EacsGuidelines-v6.1-2edition.pdf.

38. Sermwittayawong N, Singh B, Nishibuchi M, Sawangjaroen N, Vuddhakul V: Human Plasmodium knowlesi infection in Ranong province, southwestern border of Thailand. Malar J 2012, 11:36.

39. WHO: World Malaria Report 2012. 1st edition. Geneva: World health organisation; 2012. http://www.who.int/malaria/publications/ world_malaria_report_2012/report/en/index.html.

40. Willmann M, Ahmed A, Siner A, Wong IT, Woon LC, Singh B, Krishna S, CoxSingh J: Laboratory markers of disease severity in Plasmodium knowlesi infection: a case control study. Malar J 2012, 11:363.

\section{doi:10.1186/1475-2875-12-283}

Cite this article as: Ehrhardt et al.: Plasmodium knowlesi and HIV coinfection in a German traveller to Thailand. Malaria Journal 2013 12:283.

\section{Submit your next manuscript to BioMed Central and take full advantage of:}

- Convenient online submission

- Thorough peer review

- No space constraints or color figure charges

- Immediate publication on acceptance

- Inclusion in PubMed, CAS, Scopus and Google Scholar

- Research which is freely available for redistribution

Submit your manuscript at www.biomedcentral.com/submit
C) Biomed Central 